\section{Fall colours}

This edition of marketplace includes expansions to chromosome paint kits, apoptosis kits, a random peptide display library, designer oligos and other useful software as well as a genetical service for breeders.

\begin{tabular}{|c|}
\hline $\begin{array}{l}\text { For more } \\
\text { information call: }\end{array}$ \\
\hline $\begin{array}{l}\text { Applied Spectral } \\
\text { Imaging } \\
1-619-929-2840\end{array}$ \\
\hline $\begin{array}{l}\text { Cambio } \\
+44(0) 1223 \\
366500\end{array}$ \\
\hline $\begin{array}{l}\text { Amersham } \\
\text { International plc } \\
+44(0) 1494 \\
544000\end{array}$ \\
\hline $\begin{array}{l}\text { Promega } \\
1-800-559900\end{array}$ \\
\hline $\begin{array}{l}\text { Boehringer } \\
\text { Mannheim } \\
+44(0) 1273 \\
480444\end{array}$ \\
\hline $\begin{array}{l}\text { Invitrogen } \\
+31(0) 594515 \\
175\end{array}$ \\
\hline $\begin{array}{l}\text { National } \\
\text { Diagnostics } \\
1-404-699-2121\end{array}$ \\
\hline $\begin{array}{l}\text { National } \\
\text { Biosciences, Inc } \\
1-612-550-2012\end{array}$ \\
\hline $\begin{array}{l}\text { Secta } \\
\text { Information } \\
\text { Systems } \\
+44(0) 121 \\
3211717\end{array}$ \\
\hline $\begin{array}{l}\text { Perkin Elmer } \\
\text { (PE Zoogen) } \\
1-415-638-5530 \\
\text { or } \\
1-203-761-5400\end{array}$ \\
\hline
\end{tabular}

This autumn cytogeneticists, cancer researchers and other interested parties can visualize all human chromosomes at once in different colours using spectral karyotyping (SKY), a revolutionary whole genome scanning method highlighted by Reid et al. in the July 26 issue of Science. Using Applied Spectral Imaging's SpectraCube ${ }^{\mathrm{TM}}$ technology, following multi-colour fluoresence in situ hybridization (FISH), definitive emission spectra for each chromosome can be measured simultaneously at all points in a sample allowing rapid and automatic identification of chromosomal aberrations. The SD200 Spectral Bio-Imaging System includes an interferometer coupled to a CCD camera, a computer and powerful spectral image analysis software.

Cambio has expanded its STAR*FISH ${ }^{\mathrm{TM}}$ range of chromosome paints to include telomeric probes, giving the study of telomeres, their action in cell division and their rela tionship to cancer a boost.

Vivid pink is the order of the day for those using Amersham International's SeeDNA ${ }^{\mathrm{TM}}$, a new inert polymer-based coprecipitant which overcomes many of the problems associated with ethanol precipitation of small quantities of nucleic acid. Pink pellets are clearly visible under normal light conditions or as a fluorescent pellet under UV light. SeeDNA does not interfere with subsequent experimental procedures, is compatible with many applications but is not recommended for procedures that require spectrophotometric measurements or methods that are based on rhodamine detection.

A genetics clinical and laboratory management system, GENESIS, has been developed by Secta Information Systems to cover all aspects of cytogenetics and molecular genetics. Written in Microsoft Foxpro ${ }^{\circledR}$ for Windows ${ }^{\circledR}$, it is a quick, reliable and efficient multi-functional, multi-user database that covers various aspects of patient records (including history, pedigree and costs of tests), cytogenetics (karyotypes), DNA tests (gel storage) and more.

Researchers investigating pro- grammed cell death can now benefit from the rapid detection and quantification of apoptosis using a number of kits that are available. Promega offers a fluorescein-based system for in situ detection at the single cell level. Nuclear fragmentation can be measured in a variety of systems including cell suspensions and even in formalin fixed, paraffin embedded tissue sections using their Apoptosis Detection System which measures the catalytic incorporation of fluorescein 12-dUTP at 3'-OH DNAends. A unique simple one-step microplate immunoassay method, taking less than 4 hours with no pre-labelling of cells required, is offered by Boehringer Mannheim for the specific detection and quantification of nucleosomes in many different cell systems. Cell Death Detection ELISA $^{\text {PLUS }}$ uses a one-step immunoreac-

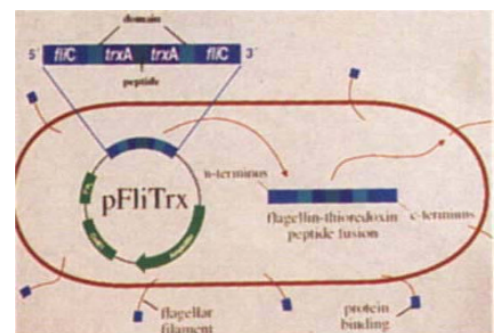

FliTrx Random Peptide Display Library

tion where a mixture of the sample is incubated with biotin-labelled antihistone and peroxidase conjugated anti-DNA antibodies in a strepavidincoated microplate.

Molecular biologists with interests in protein-protein interactions will find Invitrogen's innovative FliTrx Random Peptide Display Library ${ }^{\mathrm{TM}}$ useful. Bacteria flagellum display the libraries on the surface of E. coli. Random peptides are positioned in a flagella(Fli)-Thioredoxin(Trx) fusion protein which is exported and assembled into partly functional flagella. Proteins are screened by panning and plasmids isolated from positive clones are sequenced, eliminating phage infection or isolation steps required by phage-based display methods.

OligoPrep ${ }^{\mathrm{TM}}$, a totally synthetic meltable gel electrophoresis matrix

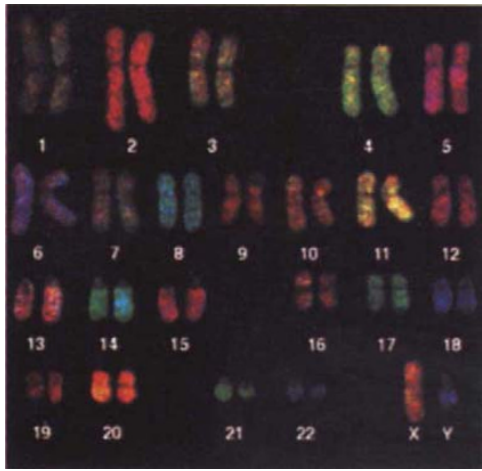

Spectral karyogram of human chromosomes after hybridization of a probe cocktail containing painting probes for all 24 chromosomes

with superior resolution capabilities, can be used to separate, purify and recover DNA and proteins. Produced by National Diagnostics, OligoPrep can be used to separate 5 to 3,000 base pairs or proteins from 8 to 220 $\mathrm{kD}$ and, to obtain immediately usable samples by simply excising and melting the relevant gel section which melts only once and remains liquid even at room temperature.

With the release of version 5.0 OLIGo Primer Analysis Software for the Macintosh, National Biosciences introduces a powerful and easy to use 'expert system' which provides 25 new features to assist the search, analysis, selection and management of optimal oligonucleotides for PCR, sequencing, site-directed mutagenesis and other hybridization applications. All selected primer pairs are listed with position number, optimal annealing temperature, $\mathrm{PCR}$ product size and GC content of PCR product. The multifuctional program also calculates hybridization temperature and secondary structure of oligos among the many features it offers.

And finally, attention breeders and owners of other species, Perkin Elmer's acquisition of Zoogen to be called PE Zoogen has plans to offer a wide array of genetical analysis services. Services already provided such as Sex made Easy ${ }^{\circledR}$, a DNA-based gender-determination assay for exotic birds, and genetical analysis services to breeders of ratites (flightless birds), were recently extended by a genetic system called DNA PawPrint ${ }^{\mathrm{TM}}$, for the identification of canines for parentage testing and security purposes. In addition to the DNA marker set already available for cattle, PE Zoogen is developing marker sets for other species.

Notes complied by Vasanthi Vanniasingham. 